\title{
Development of the Innovation Infrastructure of Modern Education in the Republic of Tatarstan
}

\author{
Irina Arkadevna Kodolova
}

Lilia Mirgaziyanovna Yusupova

Tatyana Viktorovna Nikonova

Elvira Distantovna Khisamova

Elvira Nurkhatovna Mendybayeva

Institute of Management, Economic and Finance, Kazan Federal University, Kazan, 420008, Russia

Doi: 10.36941/jesr-2019-0005

\section{Abstract}

The formation of a new efficient education based on knowledge, the development of innovation, the creation of innovation infrastructure, high-tech sectors of the education, small education as the main conductor of mass innovations are becoming priority areas of innovation policy in the Republic of Tatarstan. The article discusses the development of innovative infrastructure of the Republic of Tatarstan. The characteristic of the innovation infrastructure of the Republic of Tatarstan in the modern development of the Modern education is given. Development of innovation infrastructure in the region on the basis of the cluster approach is shown. Some comparative indicators of the innovative development of the Republic of Tatarstan with the regions of the Volga Federal District are given. Management recommendations for the development of innovation at the regional level are developed.

Keywords: innovation, innovation activity, level of innovation activity, innovation infrastructure, cluster approach, innovation potential, innovation activity in the Volga Federal District regions

\section{Introduction}

The efficiency of innovation activity largely depends on the state of the innovation infrastructure, which presents a complex of interrelated structures that serve and ensure the implementation of innovation activity. According to the Strategy of Social and Educational Development of the Republic of Tatarstan until 2030, the Republic of Tatarstan will make the most significant contribution to the implementation of federal priorities in such areas as an innovative education and innovation ecosystem. The strategy pays significant attention to the interaction of science, education, education and government within the cluster. Cluster organization assumes the expansion of education opportunities to participate in the development and implementation of the most important directions of the educational policy of the Republic of Tatarstan.

\section{Research methodology}

To ensure the coordinated functioning of the subjects of innovation, the development of innovation infrastructure, increase the efficiency of state regulation of the innovation sector in the region, an 
analysis of the indicators of the main indicators of innovation activity is necessary. An analysis of the development of innovation infrastructure in the Republic of Tatarstan was carried out according to the data of the Territorial body of the Federal State Statistics Service for the Republic of Tatarstan for the last ten years. The research method was the comparative indicators of innovation activity in the Republic of Tatarstan and in the regions of the Volga Federal District (VFD).

The Republic of Tatarstan is currently one of the leading Russian regions, where innovative approaches and modern technologies are being introduced in many areas, and above all in oil production, oil refining, petrochemistry, engineering, IT, high-tech medicine. The presence of a modern innovation infrastructure and active state support ensured the formation in the republic of favorable conditions for increasing innovation activity. According to the rating of innovation activity of the regions, which is annually compiled by the National Association of Innovation and Information Technology Development, Tatarstan took the second place in 2014 (Rad and Hosseini, 2016; Kodolova et al., 2017).

In 2015, the Strategy of Social and Educational Development of the Republic of Tatarstan till 2030 was adopted, one of the goals of which was the formation of an innovative education based on knowledge. The strategy of the socio-educational development of the Republic of Tatarstan until 2030 identifies the following key objectives of innovation policy in the republic: stimulating the usage of advanced world technologies, providing support for the commercialization of scientific research, and promoting technology transfer; stimulating the introduction of lean production principles in enterprises, stimulating innovative entrepreneurship, forming a list of key cluster innovations, defining a portfolio of innovative cluster projects, ensuring a continuous interaction within clusters within the framework of the "triple helix": education-science-authority.

The tool for this implementation is the cluster approach to innovation. A balanced system of public, private and public-private institutions ensures the sustainable development of competitive clusters, small and medium-sized education, the development of innovation infrastructure and external integration (Khosravani Farahani \& Mahmodi Lafva, 2016).

On the basis of the cluster approach the development of innovation infrastructure in the Republic of Tatarstan implies:

- the creation of innovative clusters in conjunction with existing educational (mainly educational) clusters; innovative potential of existing educational clusters will stimulate the development of innovative clusters;

- formation of integrated technological chains, ensuring an increase in the share of value added produced in the country;

- the transition from macroeducational regulation to educational, technological and cluster policies, using active methods of state intervention in educational development;

- state assistance in promoting domestic goods in the domestic and foreign markets;

- interregional integration in the development of cluster policy and the formation of crossborder clusters;

- public policy to stimulate the development of relations between universities, research institutions and educations and attract large foreign firms to the centers of knowledge and entrepreneurship;

- the formation of centers of competitiveness and high technology, technopolises at the base and around universities;

- "pulling up" backward areas through the formation of clusters based on innovative technologies.

In Tatarstan, it is planned to form 10 innovation clusters, which are a "pilot" project within the National Technology Initiative. A special role in the innovation development of the republic is played by the Kamsky innovation territorial production cluster - InnoKam, which is the main point of educational growth of the Republic of Tatarstan. Cluster specialization - oil refining, petrochemistry and automotive. The cluster share in the gross regional product of the republic is over $25 \%$, and the volume of investments is about $40 \%$ (Nikonova et al., 2018; Kodolova et al., 2017).

By 2020, it is planned to increase the volume of educational production of the Kamsky innovation cluster by 3 times. To this end, large investment projects are being implemented in the priority sectors of education in the republic. Such as the construction of a plant for the deep 
processing of oil by JSC TANECO, the construction of the TAIF-NK complex for the deep processing of heavy residues, the construction of the ammonium, methanol and carbamide production complex Ammonium in Mendeleevsk, the construction of the silicon organic materials production center KZSK-Silicon.

The key role in the Kama cluster is assigned to the special educational zone of educational production of the type "Alabuga", which includes 48 resident companies. Residents of the special educational zone are represented by three key clusters: the production of automobiles and automotive components, the processing of polymers into finished products, the production of building materials. Projects in the food education, woodworking, glass production, composite materials, and mechanical engineering are being implemented in The special educational zone Alabuga (Yusupova et al., 2017; Wyrasti et al., 2019).

In the innovation-active regions, as a rule, there is a positive education climate. The education climate is necessary to attract foreign education. Every year millions of dollars of foreign investment flow into the education of the Republic of Tatarstan. Investments were made mainly in the development of processing industries $-25.4 \%$, of which $-50.8 \%$ accounted for the production of petroleum products, transport and communications $-21.6 \%$, in operations with real estate, rent and provision of services $-17.0 \%$ in mining $-10.0 \%$.

In modern educational conditions, special attention is paid to the development of knowledgeintensive high value-added sectors of the education, whose products and services are competitive on the world market. The greatest potential here are information and communication technologies, the development of which is a priority in the Republic of Tatarstan. At present, the republican program "Development of Information and Communication Technologies" Open Tatarstan for 20142020 " is being successfully implemented. In Tatarstan, formed a new administrative unit - the city of Innopolis. The intellectual core of the city is Innopolis University. This is a new Russian university, created with Kazan Federal University and the leading US IT university Camegie Mellon (Kodolova \& Fesina, 2016; Matias \& Sousa, 2017).

An important condition for the innovative development of the region is the issue of the commercialization of intellectual property. In the Republic of Tatarstan, together with Rospatent and the World Bank, an Intellectual Property Market Development Program was developed in the Republic of Tatarstan for 2013-2020. The program is aimed at forming an effective mechanism for obtaining educational benefits from scientific and technical, innovation and production activities, increasing the competitiveness of national producers in the domestic and foreign markets through effective management of intellectual property.

A significant role in the interaction of science and education is played by universities of Tatarstan. Currently, leading universities of the republic are working on the development and creation of new innovative products for enterprises of the Republic of Tatarstan in the following areas: advanced materials, info-communication and space technologies, biomedicine and pharmaceuticals.

Examples of the commercialization of innovation results are at Kazan Federal University, Kazan National Research Technical University, Kazan National Research Technological University, Kazan State Energy University.

The key factors constraining the innovation activity of enterprises and organizations include: insufficient own financial resources and high cost of innovations, an undeveloped system of state financial support for innovation, a high level of risk, an undeveloped innovative potential of organizations, a lack of qualified personnel and a number of others (Sadeghpour et al., 2017).

The results of the formation and development of innovation infrastructure in the Republic of Tatarstan can be analyzed by considering the indicators of innovation dynamics in the Volga Federal District (VFD), table 1. 
Table 1. Indicators of innovation dynamics in the Volga Federal District

\begin{tabular}{lcccccc}
\hline Subject & $\begin{array}{c}\text { Number of organizations } \\
\text { performing } \\
\text { scientific research } \\
\text { and development }\end{array}$ & $\begin{array}{c}\text { The level of innovation } \\
\text { activity of organizations, } \\
\text { the percentage }\end{array}$ & $\begin{array}{c}\text { The volume of innovative goods, works, } \\
\text { services of educational organizations } \\
\text { (million rubles) }\end{array}$ \\
\cline { 2 - 7 } & $\mathbf{2 0 1 5}$ & $\mathbf{2 0 1 7}$ & $\mathbf{2 0 1 5}$ & $\mathbf{2 0 1 7}$ & $\mathbf{2 0 1 5}$ & $\mathbf{2 0 1 7}$ \\
\hline Republic of Tatarstan & 121 & 114 & 20,5 & 22,2 & 365965,3 & 426524,4 \\
\hline Saratov region & 56 & 60 & 6,3 & 5,0 & 16110,5 & 9477,8 \\
\hline Republic of Udmurtia & 35 & 33 & 10,2 & 6,7 & 16692,2 & 56522,5 \\
\hline Republic of Bashkortostan & 74 & 72 & 9,1 & 7,4 & 134317,8 & 107836,4 \\
\hline Nizhny Novgorod Region & 101 & 90 & 13,5 & 11,1 & 135798,1 & 192293,5 \\
\hline Orenburg region & 35 & 32 & 10,8 & 6,4 & 14545,6 & 23067,3 \\
\hline Penza region & 29 & 27 & 14,7 & 20,7 & 5745,2 & 14449,5 \\
\hline Perm region & 71 & 65 & 10,5 & 6,4 & 83057,6 & 211873,6 \\
\hline Kirov region & 27 & 25 & 9,8 & 9,5 & 8670,7 & 13035,3 \\
\hline Mari El Republic & 8 & 8 & 8,3 & 7,1 & 10174,1 & 14818,5 \\
\hline Republic of Mordovia & 26 & 17 & 16,6 & 12,5 & 33365,1 & 43817,4 \\
\hline Chuvash Republic & 25 & 28 & 24,0 & 24,7 & 16598,4 & 21124,6 \\
\hline Samara region & 76 & 64 & 5,0 & 4,3 & 217788,9 & 196348,3 \\
\hline Ulyanovsk region & 31 & 28 & 5,2 & 3,4 & 30656,8 & 28422,6 \\
\hline
\end{tabular}

The number of organizations performing research and development in the Volga Federal District decreased in 2017 compared to 2015 in almost all the regions of the district. The level of innovative activity of organizations also decreased in the period from 2015 to 2017 . The growth of the level of innovative activity of organizations was observed only in two subjects - in the Republic of Tatarstan and in the Penza Region. The volume of innovative products grew by $24 \%$ in the whole federal district. The growth in the volume of innovative products was accompanied by an increase in expenditures on research and development by the subjects of the Volga Federal District, however, the growth rates of the indicators were unbalanced by region.

The Republic of Tatarstan is one of the most active participants in the innovation process among the regions of the Volga Federal District. According to the level of cumulative innovation activity (the ratio of the number of organizations implementing innovations to the total number of surveyed organizations), the VFD regions can be divided into three groups.

The first group includes the leading regions: the Chuvash Republic $(24.7 \%)$, the Republic of Tatarstan (22.2\%), the Penza Region (20.7\%), the Republic of Mordovia (12.5\%), the Nizhny Novgorod Region (11.1\%). In 2017, the Penza region entered the group of leaders, the level of innovation activity in the region increased significantly from $11.4 \%$ in 2012 to $10.7 \%$ in 2017 . In the Republic of Mordovia, the rate of innovation activity sharply decreased from $31.1 \%$ in 2012 up to $12.5 \%$ in 2017 , pic. 1 .

The second group includes - the Kirov region (9.5\%), the Republic of Bashkortostan (7.4\%), the Republic of Mari El (7.1\%), the Udmurt Republic (6.7\%), the Orenburg Region $(6.7 \%)$ and Perm Krai $(6.7 \%)$. The third group includes the remaining regions of the district, the level of innovative activity in them varies from 5\% (Saratov region), $4.3 \%$ (Samara region), to $3.4 \%$ (Ulyanovsk region).

According to the indicator "The share of innovative goods, works and services in the total volume of products shipped in 2017." In the first place in the district is the Republic of Mordovia (29.0\%), the Republic of Tatarstan (20.5\%), Samara region (16.1\%), pic. 2. 


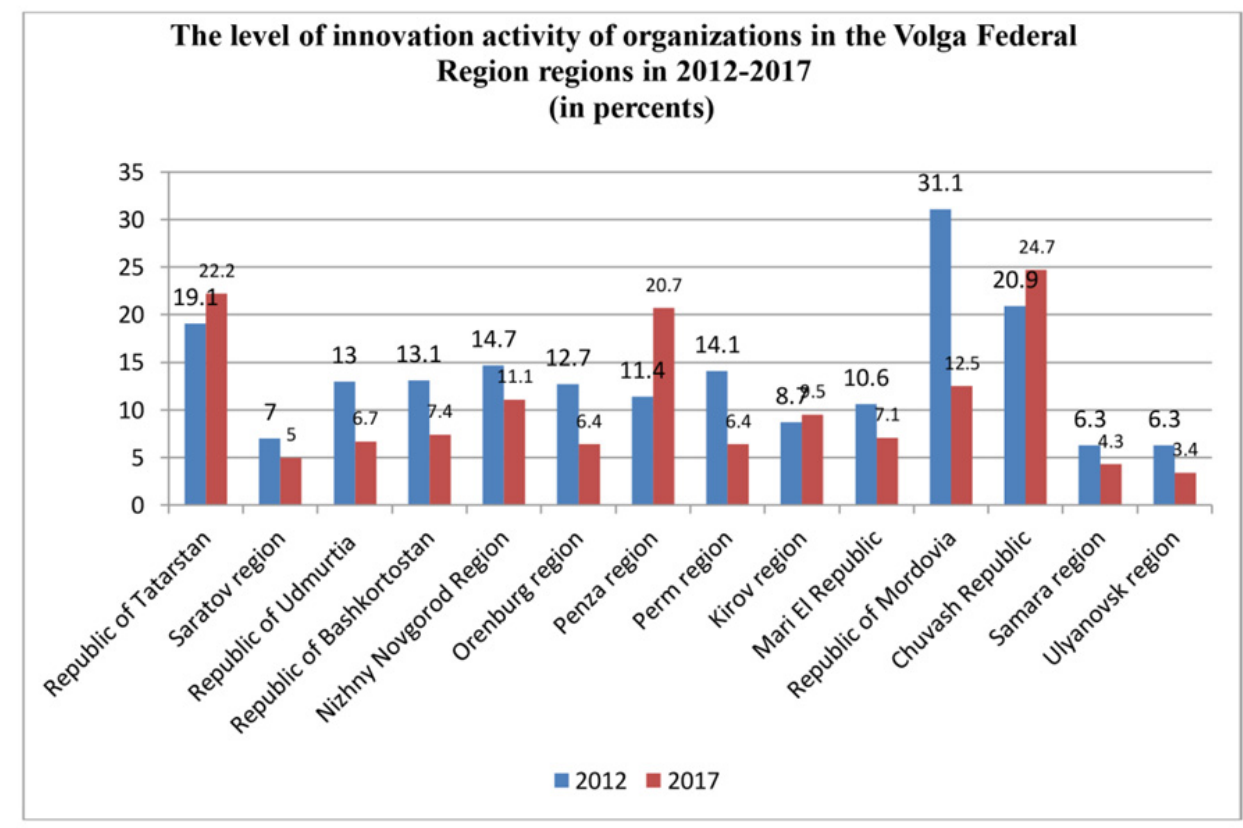

Pic. 1. The level of innovation activity of organizations in the VFD regions

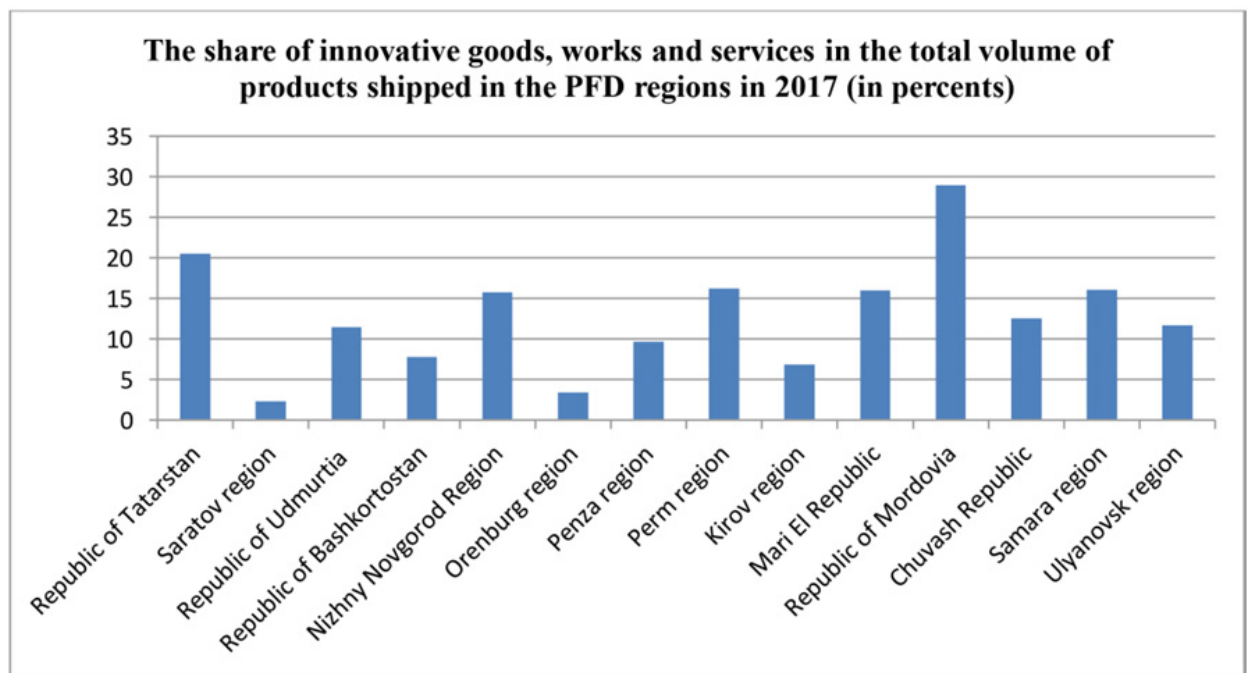

Pic. 2. The share of innovative goods, works and services in the total volume of products shipped in the PFD regions

In 2017, the Republic of Tatarstan (4,26524.4 million rubles) took the first place in terms of the volume of shipped innovative products, significantly ahead of Perm Krai (211873.6 million rubles) and Samara region (196348,3 million rubles), pic. 3 . 


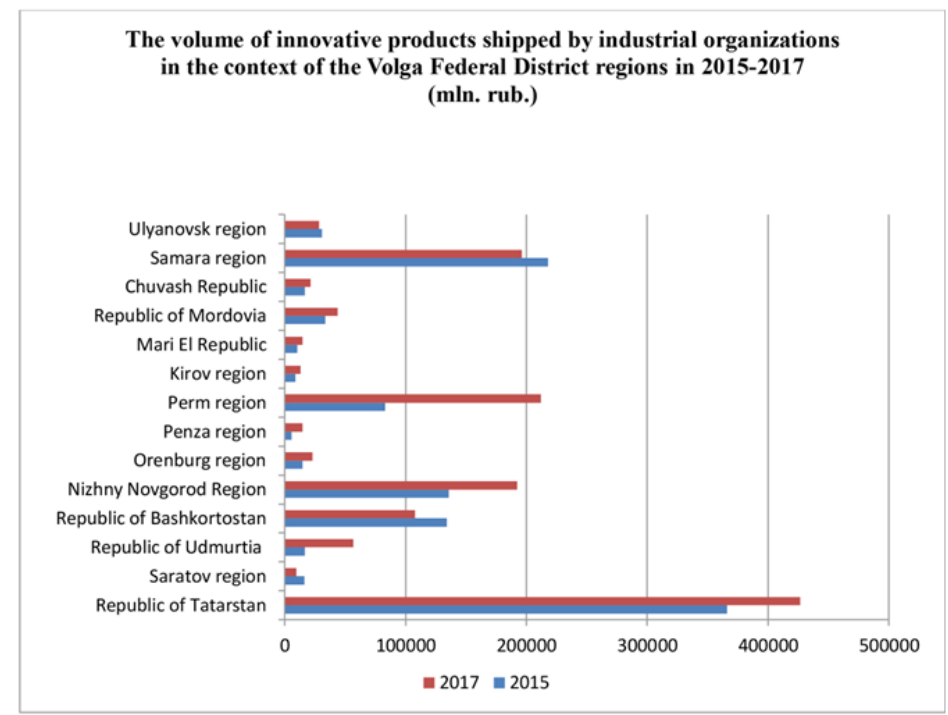

Pic. 3. The volume of innovative products shipped by educational organizations in the context of the Volga Federal District regions

In the first and second places in terms of the cost of technological innovation are the Nizhny Novgorod region (94979.2 million rubles) and the Republic of Tatarstan (78404.6 million rubles). Perm Krai ranks third in terms of the cost of technological innovations in 2017, which amounted to 33,459.7 million rubles, pic. 4.

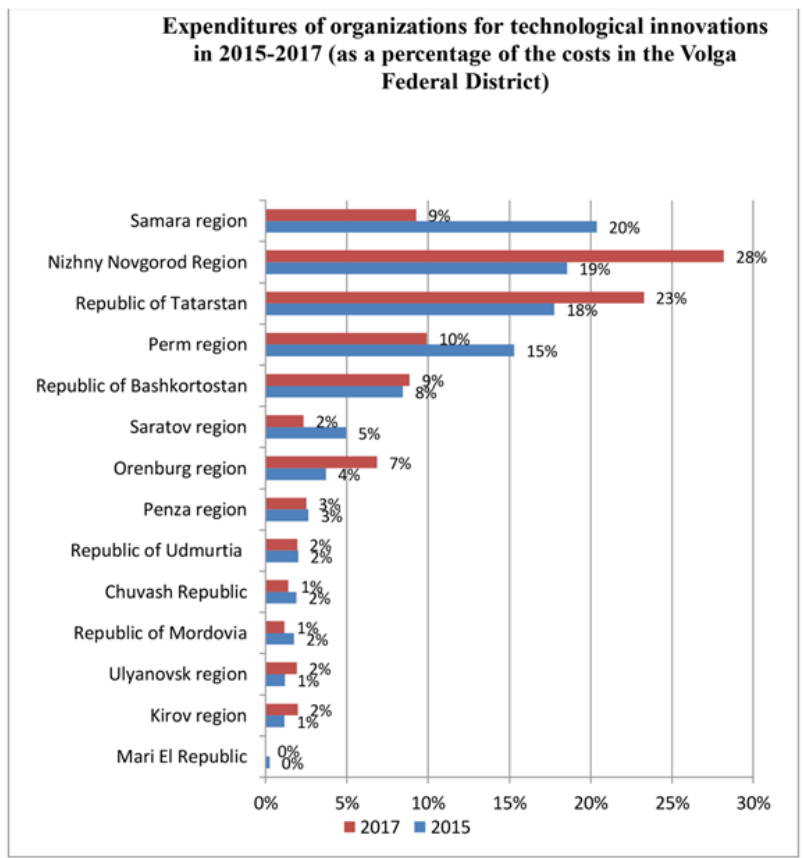

Pic. 4. The volume of expenses for technological innovations in the context of the Volga Federal District regions in 2015-2017 
Let us consider the dynamics of changes in the cost of technological innovations of organizations of subjects of the Volga Federal District for 2015-2017. The costs of the VFD organizations for technological innovations in 2017 increased by $12.7 \%$ (from 300152.3 million rubles to 336919 million rubles) (Kodolova, 2016).

The share of expenses of the Nizhny Novgorod region is $28 \%$ of the total. The share of expenses of the Republic of Tatarstan is $23 \%$ of the total expenses in the district. A positive leap is demonstrated by the Nizhny Novgorod Region and the Republic of Tatarstan in increasing the volume of expenditures on technological innovations. In the Perm region and the Samara region, a decrease in the cost of technological innovation is observed.

The list of leading regions for this indicator is completed by the Republic of Bashkortostan (in 2017 - 29888.7 million rubles). The tenth part of all expenses in the district falls on each of the regions: Saratov region, Penza region, Chuvash Republic, Udmurt Republic, Orenburg region. The last group (less than 1\% of all costs) comprised the Republic of Mordovia, the Kirov region, the Ulyanovsk region and the Republic of Mari El.

\section{Conclusion}

The main direction of improving the regional education in the Republic of Tatarstan is the transition to an innovative development model, the creation of a modern innovation infrastructure, the improvement of the mechanism for effective management of innovation processes, the development of regional scientific and scientific-technical cooperation of subjects of the Volga Federal District, increasing the activity of participants in the innovation process and ensuring the growth of innovative goods, works and services.

According to the authors, the key tasks in the implementation of the development of the innovation infrastructure of the Republic of Tatarstan are:

- creation of a regional innovation infrastructure, represented by a network of innovative high-tech clusters;

- stimulating demand for innovation and the effectiveness of research, creating the prerequisites and conditions for the formation of sustainable research and production ties, the integration of Russian innovation clusters into the global market for high-tech products;

- creation of favorable conditions for technological modernization of educational sectors based on advanced production technologies and integration with global technological innovation complexes in order to form an innovation market;

- the formation on the basis of public and private partnership of priority areas for the development of science, technology and technology, within which the competitiveness of individual sectors of the regional education is provided mainly by domestic technological developments.

\section{Acknowledgements}

This scientific research is completed under the Russian Government Program on the Competitive Growth of Kazan Federal University.

\section{References}

Kodolova, I. A., Khisamova, E. D., \& Hasbiullina, G. M. (2017). Strategy of innovative development for the republic of tatarstan. QUID: Investigación, Ciencia y Tecnología, (1), 1407-1414.

Kodolova, I. A., Yusupova, L. M., Nikonova, T. V., Khisamova, E. D., Hasbiullina, G. M., \& Solodkova, I. M. (2017). The dynamics of innovative activity developmemt: the enterprises of Tatarstan. Astra Salvensis, $2017,415$.

Kodolova, I. A. (2016). Innovative development of enterprises of the Republic of Tatarstan and the regions of the Volga Federal District. Monograph ed. Dr. econ. Sciences Babkina A.V.- St. Petersburg .: Publishing house SPbPU, p.162-186.

Kodolova, I. A., Fesina, E. L. (2016). Innovative development of the enterprises of the Volga Federal District. The Kazan social and humanitarian bulletin, 5, 28-32. 
Nikonova, T. V, Yusupova, L. M., Kodolova, I. A. (2018). Cluster approach as a factor of increasing the investment attractiveness of the region. Journal of Social Sciences Research, Is. Special Issue 5, 70-74.

Yusupova, L. M., Nikonova, T. V., Kodolova, I. A., Kokh, I. A., \& Araslanova, K. M. (2017). Trends and problems of development of life insurance investments in the russian market. QUID: Investigación, Ciencia $y$ Tecnología, (1), 1529-1532.

Rad, K. B., \& Hosseini, S. M. (2016). Study of Forbidden Income in Islamic Law. UCT Journal of Social Sciences and Humanities Research, 4(01), 12-15.

Khosravani Farahani, H., \& Mahmodi Lafva, M. (2016). An Empirical Study: Survey of Relationship between Marketing Mix and Customers' Loyalty (Case Study: SMEs in Ghazvin city) . UCT Journal of Management and Accounting Studies, 4(1), 17-22.

Wyrasti, A. F., Sa'dijah, C., As'ari, A. R., \& Sulandra, I. M. (2019). The Misanalogical Construction of Undergraduate Students in Solving Cognitive Conflict Identification Task. International Electronic Journal of Mathematics Education, 14(1), 33-47. https://doi.org/10.12973/iejme/3961

Matias, N. R., \& Sousa, M. J. (2017). Mobile Health, a Key Factor Enhancing Disease Prevention Campaigns: Looking for Evidences in Kidney Disease Prevention. Journal of Information Systems Engineering \& Management, 2(1), 3. https://doi.org/10.20897/jisem.201703

Sadeghpour, F., Far, M. G., Khah, A. R., \& Akbardokht Amiri, M. A. (2017). Marketing Strategic Planning and Choosing the Right Strategy using AHP Technique (Case Study: Ghavamin Bank Mazandaran). Dutch Journal of Finance and Management, 1(2), 45. https://doi.org/10.29333/djfm/5821 